\title{
Government Planning to Improve Quality of China's Basic Education
}

\author{
Li-Na ZHANG $^{a}{ }^{a}{ }^{*}$, Xiao-Dong PAN ${ }^{b}$, Dong-Qing BAI ${ }^{c}$ \\ Teachers' College Shenyang University, Shenyang, China \\ a1402678739@qq.com, b782024347@qq.com, ${ }^{\mathrm{c}} 792779235 @ q q . c o m$
}

Keywords: Planning, Quality, Basic education.

\begin{abstract}
On March 3, 2004, the State Council approved and disseminated the 2003-2007 Action Plan for Invigorating Education. This plan is the fundamental blueprint for further implementing the strategies of 'Rejuvenating China Through Science and Education”. In the new Action Plan, universalizing the nine-year compulsory education and improving the quality was the priority among priorities in developing education. In order to improve quality of basic education, more reforms and innovation in education in terms of increased funding, improvements in the corps of teachers, in the curriculum and teaching and in management, are all needed for sustainability (Zhou Ji, 2003)[1].
\end{abstract}

\section{Introduction}

This paper presents government-planning relating to the quality improvement of basic education in China. It presents the data on the planning for finance and resources, the management system of education, training and professional development curriculum and assessment, based on documentary analysis at the policy level for improving quality of basic education in China.

\section{Planning for Finance and Resources}

It is generally accepted that the most common cause that has hampered the effort at enhancing the quality of education is inadequate finding. Inadequate funding inevitably leads to an insufficient supply of all types of inputs to he education system, such as facilities, teachers' qualifications and training, curriculum content, textbook and learning materials, etc. (the box of Table 2). The provision of adequate funding and resources available to schools is, o a great extent, a decisive factor in the quality of education. So increasing input into education or enhancing the provisions for education has to be plan first, along with improvement in the investment efficiency (MOE, P.RC. 2003)[2].

The fourth measure refers to the reform and improvement of educational input system. It includes establishing an educational financial system compatible to the public financial system, expanding fund-raising channels, perfecting the national education facilitation and social education facilitation system, tightening up management and improving efficiency (Zhou Ji, 2004)[3].

The review of planning for finance and resources available for education offered recommendations for quality enhancement. They are as follows:

--- In the near feature, financial resources should be concentrated in order to improve the schooling conditions step by step so as to lay a solid foundation for the quality improvement of the whole nation.

--- In basic education, more efforts should be devoted to the development of the standard construction of schools to solve the problem of shortage of teaching tools, experimental equipment's and books.

--- Governments at all levels should provide preferential policies for the publication of textbooks and teaching and learning assistant boos, and for the development, production and supply of teaching equipments (MOE P.R.C. 2003) [2].

According to the UN China, it is stated that 'funding is essential, and education needs more and 
continued support from the government' (UN China, www.unchina.org.12.07.05)[4]. In China, central government budgetary allocation for education is being increased by one percent point annually from 1998 to 2002. Local Government are required to make a similar contribution. So that educational expenditure in fiscal budget reached 4\% of GDP. By 2010, the figure needs to be further increased to the level of middle-developed countries.

In addition, in China, some 64 percent of its population lives in rural areas including the western region. In order to fulfill the objectives of improvement in the quality of basic education, Education Minister Zhou Ji pledge China will allocate more funds from the central budget to these areas, with 10 billion yuan (US S 1.2 billion) each year (China Development Gateway 2004)[5]. In 2003, 3 billion yuan was allocated by the Central Government as a special fund to support compulsory education in impoverished areas; 2 billion yuan, out of a planned 6 billion yuan, was spent on the renovation of dilapidated school buildings; 1.4 billion was used for modem facilities for remote education; expense for free textbooks have been increased from 2000 million yuan to 400 million yuan allotted by the Central Government (ibid).

Vice-minister of Education Wang Zhan is optimistic that by 2010, China will see a population of 400 million enjoying high quality basic education (People's Daily 2001)[6].

\section{Planning for the Management System of Education}

Among the indicators of the overall improvement of educational quality, an efficient and efficient educational management system as a contextual element is recognized to be fundamental to quality of education. Management performs a number of key functions in strengthening educational quality, such as ensuring implementations of national policies and directives, ensuring an adequate allocation of necessary resources, providing teachers and principals with necessary materials, innovative and professional support, as well as identifying the task of monitoring and evaluating performance.

So changing the management system of education has also been planned a the central government level 'Draft Decision on Reforming the Education System' issued in the May 1985 National Conference on Education. The strategies that were suggested for quality enhancement were:

--- The state education commission is responsible for formulation rules, principles and policies and general development program and basic education system.

-- Local government should be responsible for basic education under the guidance of state.

---Provincial governments should be responsible for the general development affairs of basic education, including mapping out development programmers and primary school teaching plans and organizing the assessment of the result of compulsory education in their own areas.

--- County (city, district) governments are responsible for specific matters relating to compulsory education, including managing educational funds, principals and teachers of primary and secondary schools and providing specific guidance to teaching at primary and secondary schools.

---Township governments are responsible for implementing the compulsory education programme in their own areas (Education 2004)[7].

The new planning was mobilising an incentive for local governments, especially these of the counties and townships which are in the control of the management of personnel and finance. In addition, local governments are responsible for policies and regulations for leadership as well as the management and inspection of schools, but they have no regulations stipulating the qualifications for key educational administrators. Thus the quality of the management mainly relies on the experience and educational background of the individuals in charge. To ensure the improvement of compulsory education, the new management system also focuses on the county government for taking the principal responsibility. The improvement of the quality management in education is fostered through the establishment of training modes to support principal, provincial and county educational management personnel, education planners, and project management trainers, 
upgrading the competence of school, county, provincial and national level managers.

\section{Planning for Teacher Training}

Undoubtedly, good teachers are the key to good education (Garrett, 1999:31). In fact, both the quantity and quality of teachers largely determine how good education will be. Without adequate and well-trained teachers, educational quality cannot be improved. Thus, the Government has implemented the Programme for producing High Qualified Teachers and Teaching Management, in order to improve the system of teaching training and life long learning of teachers and to establish a cohort of highly qualified teachers.

On April 11, the State Education Commission issued the Suggestions on improving the Quality of Primary and Middle School Teachers during the Ninth Five-Year plan, starting that the number of Primary and middle school teachers in China should be increased to 9.88 million by 2000, with over $95 \%$ of Primary school teachers and $80 \%$ of middle School teachers holding the required diploma. The number of primary and middle School teachers holding medium and senior titles should account for 34\% and 45\% respectively(Li Haisheng, 200la)[8].

In the new Action Plan 2003---2007, the Sixth programme is the 'Programme on Building Up A Competent Teaching and Administrating Cohort'. It is stated that educational innovation and talent cultivation depends on the hard work of the teacher, as well as their qualities. The deepening of personnel system reforms for teaching staff to reinforce the management at school level should be prioritized so that all the teaching positions and different units inside schools can b planned scientifically. The teacher certificate system will be implemented wit the policy of 'accessing with qualifications, competing for vacancies, and working with employment contracts”. Additionally, this new Action Plan will further promote this practice and improve the teacher training system and the further education system for in-service teachers (Zhou Ji, 2004)[3].

According to the degree requirement set up by 'Law on Education' and 'Law on Teachers', the strategies of he plan for strengthening the improvement of quality teacher cohort are as follows:

--Increasing the proportion of teachers in primary and secondary schools who have reached the degree requirement

---Improving the ratio of backbone teachers through recruiting new teachers with high degrees

---Encouraging graduates from non-teacher training to teach in secondary schools and to serve as teachers for primary schools

---Implementing the teachers' certificate system to improve the evaluation, employment and promotion mechanism for teachers and to optimize the structure of teacher cohort.

---Improving the professional quality of teachers to encourage their loyalty to education

---Creating an environment in which teachers love the students and are respected by their students

---Improving the remuneration of teachers and solving the problems of delaying the payment of salary and of health care facility to the teachers

-- -Promoting housing construction for teachers So that the avenge houses of teachers will meet or exceed that of local people (MOE, P.R.C Planning)[9].

In turn according to what is planned above, actions have been taken to some extent. In the New Action Plan, China has given teacher training a high priority. To attract and motivate more committed teachers, China plans to allocate more funds from the central budget to pay for approximately 78 percent of local teachers' salaries (China Development Gateway 2004)[5]. To improve the teachers' quality, in addition to upgrading the unqualified teachers to meet officially required qualification levels, many more teachers are to be trained to upgrade their skills and approaches periodically to meet the ongoing curriculum reform. In addition, the National programme of United Network for education of teachers, stated in 2002, can be used not only as teacher training but also provides support and service for teachers' life-long learning in the rural areas. 


\section{Planning for Curriculum}

In China, curriculum development is the first priority to educational development. It is the material of curriculum that reflects needs of the actual situation of the society and the country, thus advanced content should be aught by teachers (Deng Xiaoping, 1983.P.53 cited in Lewin, al et 1994:155). During the late 1970s and the early 1980s, two rounds of curriculum reform for basic education have been undertaken. In 1986, a further curriculum reform for elementary and high schools was initiated. Six years later, in 1992, the central government issued and in 1994 revised, a new curriculum for the compulsory school.

There are still, however, some current conflicts and drawbacks in the current curriculum, according to Li Lanqing, the pre-minister of education: the requirements set in the syllabi are too high, the contents of textbooks are often irrelevant and inappropriate as well as Unfamiliar to children, textbooks are too difficult for the comprehensive and cognitive abilities of children at the targeted ages, some of the texts are too difficult, complicated, biased, antiquated and incorrect ( $\mathrm{Li}$ Lanqiang 2004:340) [10].In addition, learning is still focused on the passive memorisation of textbooks, also the style of teaching and learning is driven by the examination format, as an examination is the only way to assess teaching and learning achievements. To build a new balance between the design of curriculum and the needs of Chinese society, individuals, culture and national development, in 1999, MOE began to design the new basic education curriculum system for the 21st century. On February 1st, the State Education Commission decided to readjust the contents of courses offered in primary and middle schools, lowering he nominal requirements, appropriately narrowing the scope of examination and consequently pressing forward with the implementation of quality education(Li Haisheng.2001b)[11].

Thus, to improve the quality of basic education, the reform of the curriculum has inevitably evolved, including the contents of textbooks, the methodologies of learning and teaching as well as assessment. It is time for our out-dated syllabi and textbooks to be overhauled and recompiled ( $\mathrm{Li}$ Lanqing 2004:340)[10]. Curriculum developers and scholars in China planned the goals of curriculum reformation and seven goals are addressed:

---The establishment of a new curriculum philosophy or ideas

---The development of educational objectives

---The renewal of educational content and experience

---The reconstruction of a model of curriculum organization

---Innovation in curriculum materials

---The establishment of a new system of curriculum evaluation

In addition, to realize the goals of current reforms, six specific measures to upgrade teaching content and to enhance the comprehensive and practical qualities of the curriculum are also planned. They are as follows:

---Improving the system of curriculum management

---Redeveloping the mechanisms of curriculum reform

---Promoting school-based curriculum development

---Integrating information technology with curriculum

---Emphasizing teachers' professional development

---Encouraging the whole nation's participation in the reform

Great efforts have been made to carry out the piloting of new compulsory educational curriculum. The new content of the curriculum focuses more on the needs of individual and social development. For instance, in the western regions and rural areas, the contents of the curriculum are more related to the vocational training to help peasants find or create jobs and also further facilitate the economic development of agriculture and farming in rural areas. Furthermore, methodology of teaching and learning is transferring from examination-oriented o competence-oriented education, following up 
curriculum objectives and textbook compilation. Last but not least, the 'Programme for Modem Distance Education in Primary and Secondary Schools in Rural Areas' will be implemented as well. It will enable students in rural areas to share the best teaching resources, and will help 20 percent of the poorest students (24 million students) in the rural areas at basic education level (Zhou Ji, 2003)[1].

\section{Planning for Assessment}

On August 20th, 2000, the Ministry of Education issued the Suggestions on Enhancing Educational Supervision and Evaluation, bringing forward guiding suggestions on the significance of enhancing educational supervision and evaluation, its nature, the responsibilities of agencies in charge, as well a means of strengthening the leadership over the educational supervision and evaluation (Li Haisheng 2001b)[11]. The Ministry of Education then transferred the Suggestions on Enhancing Educational Supervision and Evaluation to local authorities.

On 2nd of the next May, the State Education Commission printed and issued thee Guiding Outlines for Supervision and Evaluation of Tasks Fulfilled by Common Primary and Middle Schools, apart from circulating a notice that called for putting into effect the supervision and evaluation system in primary and middle schools on a national scale prior to 1998 (Li Haisheng 2001a)[8]

To strengthen the supervision and evaluation of education, the legal system for education needs to be built up and improved. The promulgation and implementation of Law on Compulsory Education, Law on teachers and Law on Education provide a solid foundation for administrative education. During the ninth 5-Year Plan, more efforts will be intensified to assimilate and implement the promulgated laws and regulations so that all the behaviours of governments at all levels and all social sectored schools will meet the requirements set up by laws and regulations.

Furthermore, in order to ensure the effective implementation of educational policies and the ability to improve the educational quality and efficiency, a better supervision system has been established. This focuses on the implementation procedures to analyse and compare the progress with the planned objectives so that experience and lessons will be collected and responding policies will be made at the appropriate time. Consequently, based on the supervision index and the educational data collection, the educational departments of central and local environments can produce their own annual supervision report (MOE,P.R.C Planning)[9].

\section{Conclusion}

This paper illustrated briefly a synopsis of the attempts that have been made at formulating Planning to improve quality in basic education in China. To further proceed with reforms to the educational System, the Chinese government has prioritised the issue of improvement of educational quality and efficiency with strategic importance, in accordance with the development plan for national economic and social progress. Development planning and strategies for improving educational quality have been focused on the integration of planning with finance and resource, management system, teacher training, curriculum and textbooks as well as assessment. All this planning has led to a new era of quality basic education, but some aspects should also be enhanced at the lowest level organizations---basic educational schools.

\section{References}

[1]. Zhou Ji, (September 2003) Providing educution for over a billion people

http://portal.unesco.org/education/en/ev.Php-URL_ID=27733\&URL_DO=DO_TOPIC\&URL_SEC TION $=201 . \mathrm{Html}$

[2]. MoE PR. C (2003) http://www.moe. edu.cn/edoas/website18/info5515. htm

[3]. Zhou Ji (2004) 2003-2007 Action Plan for Invigorating EducationMinister for Education, P. 
R. China http://ice.nuaa.edu.cn/news/news_detail phd?/news_id = 73\&type_uid+0\&\&type=id=22 [4]. UN china (12. 07. 05) www. Unichina.org

[5]. China Development Gateway (2004) Education in Rural Areas

http://www. chinagate. com/english/14268. htm

[6]. People's Daily (June, 08, 2001) China to Make Basic Education the Priority http:// english.people.com.cn / english/201606/08/eng20010608_72119. html [7]. Education (08, 31, 2004) Basic Education in China (I) http:/english. China com/zh_bblcMa. cn/1l1020788/20040831/11856713.html [8]. Li Haisheng (12, 25, 2001) a Chronicle of Major Educational Policies of China (1997-1999) I Education Milestones 1997 http://www.edu.cn/20011225/3015272.shtml

[9]. MoE, P. R. C Planning The 9th 5-Year Plan China's Educational Developmentand the Development Outline by 2010 http://www.mor.edu.cn/english/planning_n. htm

[10]. Li, Lanqing (2004) Education for 1. 3 billion Foreign Language Teaching and

Research Press http:// english.people.com.cn / english/201606/08/eng20010608_72119.html

[11]. Li Haisheng (12, 25, 2001) b Chronicle of Major Educational Policies of China (1997-1999) III Educational Milestones 1999 http://www.edu.cn/20011225/3015279.shtml 